\title{
Kolonisatör eller turist? Frågor och arbetsuppgifter i svenska historieläromedel under en tid av kunskapsideologisk förhandling
}

\author{
Anders Persson
}

\begin{abstract}
Coloniser or Tourist?: Questions and Exercises in Swedish History Textbooks, 1927-2015. The history of History as a Swedish school subject has usually been based on two sources: curriculum plans and textbook narratives. Drawing upon more than 900 exercises that occur in 72 history textbooks published 1927-2015, this article primarily examines which different approaches to history that have been prearranged to the pupils during the second half of the last century. It is shown that a great majority of the exercises, throughout the whole period of time, prescribes a simple reproduction of unchallenged truths. It is also argued that both disciplinarian assignments and aesthetic tasks, seem to appear at least as often before, as after, the 1970s. Subsequently, especially in the 1990s, the exercises occasionally ask for the individual student's own opinions - without demanding them to consider any historical circumstances. Accordingly it is argued that while the former category of exercises most often enjoin the distanced view of the uninvolved tourist, the latter rather instructs the pupil to embrace the coloniser's self-centred perspective of the past.
\end{abstract}

Keywords • Swedish school history [svensk utbildningshistoria], textbooks [läroböcker], exercises [övningar, arbetsuppgifter], go visiting [besök]

\section{Frågan - en kunskapsideologisk markör och en del av ett skolämnes historia}

Mellan vilka år varade det trettioåriga kriget?

I vilket land utkämpades striderna?

Vem var protestanternas ledare? ${ }^{1}$

Låtsas att du är en nybyggare i Minnesota. Du har bott där något år. Ibland längtar du hem till Sverige. Du vill gärna att någon från din hemtrakt, kanske en släkting, emigrerar och bosätter sig nära den plats där du bor. Skriv ett brev hem till Sverige och berätta. ${ }^{2}$

De tre första frågorna är hämtade från en svensk lärobok i historia från 1963. De svar som begärs tycks inte bara relativt korta; det som efterfrågas framstår också som något på förhand givet. Lösningarna finns uttryckligen framskrivna i bokens text. Frågornas slutna form ger intryck av att kunskap i historia, likt ett isolerat objekt, existerar i sig

1 Sixten Björkblom, Lennart Dusing och Paridon von Horn, Historia för grundskolan årskurs 4-6 (Stockholm: Bergvalls förlag, 1963), 172.

2 Sjöberg, Sven, Utvandringen till Amerika: Arbetsområden Sverige för hundra år sedan åk 6 (Örebro: Bokförlaget Liber AB, 1968), 77-78.

Anders Persson is Senior Lecturer in History at the School of Humanities and Media Studies, Dalarna University, Sweden.

Email:ape@du.se. 
självt. Den fjärde frågan, även den formulerad i ett läromedel från 1960-talet, tycks emellertid signalera något delvis annat. I den uppmanas eleven snarare att via sin föreställningsförmåga förflytta sig till en tid och situation, som egentligen erfarits av någon annan.

Diskussionen om hur vi ska betrakta vårt förhållande till kunskaper om det förflutna, och hur vi därmed i ett skolsammanhang bör uppfatta relationen ämne-elev, har inget givet svar. ${ }^{3}$ I ett historiedidaktiskt sammanhang har exempelvis begreppet historisk empati använts för att resonera om hur elever bör närma sig tidigare generationers livsvillkor. ${ }^{4}$ Oftast har dessa resonemang laddats med förmaningar om att inte göra sig skyldig till presentism. Vikten av att uppöva en slags analytisk vetenskaplig distans till historiens aktörer har understrukits. ${ }^{5}$ Den historiska kontexten, inte egna livserfarenheter, förväntas utgöra grund för tolkningar av dåtida människors tankar och handlingar.

När Hanna Arendt anför möjligheten att gå på besök hos den andre så görs det emellertid utifrån en delvis annan kunskapsteoretisk horisont. Arendts metafor kan snarare förstås som en hermeneutisk strävan efter att söka föreställa sig hur man personligen skulle ha erfarit och hanterat en situation som egentligen upplevts av någon annan. Detta betyder inte att hon förespråkar en idé om att vi kan se tillvaron från den andres ögon. I hennes skrivande är det föreställda besöket istället förknippat med en slags dubbel tankeoperation; berättelsen om den andre behöver på en och samma gång betraktas utifrån sitt unika kulturella, sociala och historiska sammanhang, samt relateras till egna personliga erfarenheter av att vara människa. ${ }^{6}$

I den här artikeln studeras frågor som förekommer i svenska läromedel i historia. Materialet täcker en period på nära nog hundra år, men huvudintresset är riktat mot den period, 1950-1993, som i tidigare forskning beskrivits i termer av en kunskapsideologisk kamp. Mer precist formulerat, är syftet att undersöka de olika förhållanden mellan kunskaper om det förflutna och den i frågan tilltalade eleven, som påbjuds $i$ efterkrigstidens svenska historieläromedel. Mot detta motiv svarar också studiens övergripande frågeställningar.

I vilka avseenden påbjuder de undersökta frågorna svar som förutsätter att eleven...

a) involverar sina egna tankar, erfarenheter och åsikter, och/eller

b) använder sina kunskaper om dåtida sammanhang?

Det bör understrykas att syftet svarar mot en intertextuell analysnivå. Även om det är den funktionella aspekten av ett antal läromedel som uppmärksammas, så säger

3 Niklas Ammert, "Contact and Contrast: The Subject of History and Its Relation to Students 19052005," International Journal of Historical Learning, Teaching and Research 12, no. 2 (2014), 46.

4 Jfr t.ex. Stephane Lévesque, Thinking Historically: Educating Students for the Twenty-First Century (Toronto: Buffalo, 2008); Elizabeth A. Yeager et al."'Why People in the Past Acted as They Did: An Exploratory Study in Historical Empathy," The International Journal of Social Education 13, no. 1 (1998), 8-24.

5 Tyson Retz, "A Moderate Hermeneutical Approach to Empathy in History Education," Educational Philosophy and Theory 47, no. 3 (2015), 214-26.

6 Hannah Arendt, Lectures on Kant's Political Philosophy (Chicago: The University of Chicago Press, 1982), 33-35; Hannah Arendt, Människans villkor: Vita activa (Göteborg: Daidalos, 1998). Persson, Anders, "Americans and Russians as Representatives of 'Us' and 'Them': Contemporary Swedish School History Textbooks and their Portrayals of the Central Characters of the Cold War," i Teaching the Cold War, red. Barbera Christophe et.al., (New York: Palgrave Macmillan, 2019), 107-9. 
artikelns resultat inte något om den $i$ klassrummet gestaltade undervisningspraktiken. ${ }^{7}$ Undersökningen syftar inte heller primärt till att förklara förändringar över tid mot bakgrund av historiekulturella strömningar, övergripande samhällsförändringar eller utbildningspolitiska beslut. ${ }^{8}$ Ansatsen utgår emellertid från föreställningen om läromedel som en kunskapsnormerande auktoritet. ${ }^{9}$ Utifrån ett sådant perspektiv kan de inte bara förstås som konstruktioner som vidmakthåller ett samhälles sätt att se på världen; de utgör också kraftfulla markeringar av vad som räknas som kunskap. I ett sådant perspektiv torde läromedlens arbetsuppgifter kunna antas utgöra särskilt tydliga kunskapsideologiska markörer. Så har exempelvis Staffan Selander påpekat att "karaktären på frågorna i ett läromedel ramar in läsningen av texten, och definierar meningen med den". ${ }^{10}$

I linje med detta bygger denna artikel på antagandet att dessa föreskrivna arbetsuppgifter inte bara hänvisar eleven till ett specifikt ämnesinnehåll; de skickar också signaler om vad som bör betraktas som värdefulla former av kunskap, i detta fall i skolämnet historia.

\section{Kunskapsformer i det svenska skolämnet historia under hundra år}

Den tidigare utbildningshistoriska forskningen om läromedel i skolämnet historia kan ur såväl ett internationellt som ett nordiskt perspektiv, betraktas som mycket omfattande. ${ }^{11}$ Företrädesvis är det dock det narrativa innehållet som har analyserats. Jämförelsevis färre är de studier som utgått från ett uttalat kunskapsteoretiskt perspektiv. ${ }^{12}$ De undersökningar som riktats mot de kunskapsformer som påbjuds i skilda historieläromedels frågor och arbetsuppgifter, är följaktligen ännu färre. ${ }^{13}$

7 Jfr Ola Halldén, Elevernas tolkning av skoluppgiften: En beskrivning av elevers förhållningssätt till lärares frågor (Stockholm: Stockholms universitet, 1982), 1-21, 40-50.

8 Med Klas-Göran Karlssons terminologi är det således snarast "läroboken som orsak", inte läroboken som "verkan" eller som "självförståelse och tradition", som undersöks. Jfr Klas-Göran Karlsson, "Läroboken och makten: Ett nära förhållande," i Att spegla världen: Läromedelsstudier i teori och praktik, red. Niklas Ammert (Lund: Studentlitteratur, 2011), 47-53.

9 Boel Englund, "Lärobokskunskap, styrning och elevinflytande," Pedagogisk forskning i Sverige 4, no. 4 (1999), 337-38.

10 Staffan Selander, Lärobokskunskap: Pedagogisk textanalys med exempel från läroböcker $i$ historia 1841-1985 (Lund: Studentlitteratur, 1988), 37.

11 Eckhardt Fuchs och Annekatrin Bock, red. The Palgrave Handbook of Textbook Studies (New York: Palgrave Macmillan, 2018); Maria Grever och Tina Vlies, "Why National Narratives Are Perpetuated: A Literature Review on New Insights from History Textbook Research," London Review of Education, (2018), 286-301; Niklas Ammert, "Historieläromedel: en forskningsöversikt," Humanetten 37 (2016), 140-53; Kløve Juuhl, Gudrun, Magnus Hontvedt och Dagrun Skjelbred, "Læremiddelforsking etter LK06 - Eit kunnskapsoversyn," (Oslo: Utdanningsdirektoratet, 2010).

12 Maria Repoussi och Nicole Tutiaux-Guillon, "New Trends in History Textbook Research: Issues and methodologies towards a School Historiography," Journal of Educational Media, Memory and Society 2, no. 1 (2010), 164-66; Eckhardt Fuchs och Kathrin Henne, "History of textbook research," i The Palgrave Handbook of Textbook Studies, red. Eckhardt Fuchs och Annekatrin Bock (New York: Palgrave Macmillan, 2018), 25-56; Ma. Lourdes S. Nery-Cura och Allan B. de Guzman, "A rhizotextual analysis of Philippine secondary textbooks in history," Education Research Policy Practise, 17 (2018), 173-75. Notera dock däruti studier och utformningen av bilder, exempelvis nyligen i: Jörgen Gustafsson, Historielärobokens föreställningar: Påbjuden identifikation och genreförändring i den obligatoriska skolan 1870-2000 (Uppsala: Uppsala universitet, 2017).

13 David B. Lavere, "The Quality of Pedagogical Exercises in U.S. History Textbooks," The Social Studies 99, no. 1 (2008), 3-8. 
Bilden av skolämnet historias egen historia i Sverige, baseras främst på läroplansstudier och analyser av lärobokstext. I de senare fallen har det oftast varit berättelsernas innehåll, inflytandet av samtidens historiekultur och/eller historiebruk som analyserats. ${ }^{14}$ Påfallande ofta har denna forskning, såsom i Norge och Danmark, rört frågor om nationsbygge ${ }^{15}$, svenskhet ${ }^{16}$, föreställningar om Norge och nordmän ${ }^{17}$, nationell gemenskap ${ }^{18}$, Norden och det nationella ${ }^{19}$, tilltagande internationalisering ${ }^{20}$ eller bilden av den (etniskt) andre ${ }^{21}$. Länge dominerade en relativt framstegsoptimistiskt framställning. Ämnets successiva utveckling relaterades bland annat till ett tilltagande intresse för samtiden, tydligare ambitioner att förklara samhällsutveckling och ett bredare demokratifostrande kunskapsideal. ${ }^{22}$

Försöken att periodisera skolämnet historias förändrade kunskapsideal i Norden är många. ${ }^{23}$ Det tidiga 1900-talets historieundervisning har dock sedan länge förknippats med ett i grunden reproducerande kunskapsideal. Vad gäller den svenska skolan har det bland annat hänvisats till hur undervisningsplanen från 1919 föreskrev en slags färdig kanon av sedelärande skildringar, vars ofta nationalistiska undertoner förväntades fostra nya generationer av medborgare. ${ }^{24}$ Det har talats om ett klassiskt historieämne, som via förmedlandet av en aktörsdriven oemotsagd berättelse, formats i ljuset av vad Tomas Englund beskrivit som en patriarkalisk utbild-

14 Ammert (2016), 140 .

15 Lorentzen, Svein, Ja, vi elsker...: Skolebøkene som nasjonsbyggere 1814-2000 (Oslo: Abstrakt forlag, 2005).

16 Ingmarie Danielsson Malmros, Det var en gång ett land: Berättelser om svenskhet i historieläroböcker och elevers föreställningsvärldar (Lund: Lunds universitet, 2012).

17 Brit Marie Hovland, Historie som skolefag og dannelsesprosjekt 1889-1940: En historiografi ut fra folkeskolens historieloerebøker (Oslo: Universitetet i Oslo, 2016).

18 Lina Spjut, Att (ut)bilda ett folk: Nationell och etnisk gemenskap i Sveriges och Finlands svenskspråkiga läroböcker för folk- och grundskolan åren 1866-2016 (Örebro; Örebro universitet, 2018).

19 Henrik Åström Elmersjö, Norden, nationen och historien: Perspektiv på föreningarna Nordens historieläroboksrevison 1919-1972 (Lund: Nordic Academic Press, 2013).

20 Harry Haue, "Transformation of History textbooks from national monument to global agent," Nordidactica 1, (2013), 80-89

21 Janne Holmén, Den politiska läroboken: Bilden av USA och Sovjetunionen i norska, svenska och finländska läroböcker under kalla kriget (Uppsala: Uppsala universitet, 2006); Persson (2019).

22 Se särskilt Herbert Tingsten, Gud och fosterlandet: Studier i hundra års skolpropaganda (Stockholm: P.A. Norstedts \& Söners förlag, 1969), 280-81; Göran Andolf, Historien på gymnasiet: Undervisning och läroböcker 1820-1965 (Uppsala: Uppsala universitet och Skandinavien university books Esselte studium, 1972), 276-80; Selander (1988), 96.

23 Knut Kjeldstadli, Det förflutna är inte vad det en gång var (Lund: Studentlitteratur, 1998), 260-66; Tomas Englund, Samhällsorientering och medborgarfostran i svensk skola under 1900-talet: Kap 1-4 (Uppsala: Uppsala universitet, 1986a), 243, 387; Tomas Englund, Samhällsorientering och medborgarfostran i svensk skola under 1900-talet: Kap 1-4 (Uppsala: Uppsala universitet, 1986b), 511, 575; Tomas Englund, Läroplanens och skolkunskapens politiska dimension (Göteborg: Daidalos, 2005), 291-304.

24 Tingsten (1969), 134-158, 194-216; Andolf (1972) 259-75; Englund (1986a), 271-79; Ulf Zander, "Att legitimera och bli legitimerat: Historieämnet förr och nu i Sverige och annorstädes," i Historiedidaktiska utmaningar, red. Hans Albin Larsson (Jönköping: Jönköping University Press, 1998), 32-68; Henrik Åström Elmersjö, "Historia och konflikter: Historiekultur och historieundervisning inom, över och bortom gränser," Historisk tidskrift 134, no. 2 (2014), 267-77; Helén Persson, Historia i futurum: Progression i historia i styrdokument och läroböcker 1919-2018 (Lund: Lunds universitet, 2018), 92-95. 
ningskonception. ${ }^{25}$ Niklas Ammert har senare resonerat om hur det under denna i övrigt omvälvande tid, tycks ha funnits en slags outtalad idé om det förflutna som en närbelägen källa till stärkande moral och stabilitet. ${ }^{26}$

Den klassiskt nationalistiska periodens slutpunkt har definierats lite olika i den nordiska forskningen. ${ }^{27}$ I ett svenskt sammanhang har det andra världskriget ofta beskrivits som en avgörande vändpunkt. I flera fall har det gjorts gällande att 1950- och 1960-talens styrdokument (Upl55, Lgr62, Lgr 69), hellre än patriotism, markerade värdet av att låta historieundervisningen utgå från en av vetenskapssamhället fastslagen sanning. ${ }^{28}$ Det som skulle läras kunde dock fortfarande beskrivas i termer av ett redan på förhand stipulerat kunskapsobjekt. ${ }^{29}$ När Helén Persson summerar sin beskrivning av 1960-talets kursplaner i historia, är det således ännu i termer av "ett föreskrivet innehåll" och "analytisk slutenhet". ${ }^{30}$

Andra har pekat på hur 1960-talets enhetsskole- och läroplansreformer med tiden bidrog till att utmana och omförhandla historieämnets hela funktion i den svenska skolan. I dessa fall har det emellertid också understrukits hur denna omvandlingsprocess har omgärdats av en rad djupgående kunskapsideologiska spänningar. Tomas Englund talar om en dragkamp mellan en vetenskapligt rationell, och en demokratisk, utbildningskonception. ${ }^{31}$ Henrik Åström Elmersjö har på liknande sätt visat att det, i den efterkrigstida debatten om skolans historieläromedel, förekommer en rad parallella, men divergerande, dikotomier. Han uppmärksammar särskilt spänningen mellan en slags vetenskapens och pedagogikens logik. I centrum för denna diskussion stod, enligt Åström Elmersjö, frågan om hur förhållandet mellan skolkunskap och elev, egentligen borde förstås. Vid sidan av den traditionella stoffnedsippringsidén, hävdades värdet av att söka avpassa undervisningen till de ungas egen livsvärld. ${ }^{32}$

När Ammert, och senare Persson, diskuterat denna efterkrigstida förändringsprocess, har de dessutom hänvisat till en förändrad syn på dåtidens relation till den egna samtiden. De har hävdat att skolämnet historia under 1960-talet både genomsyrades av en tydlig framstegstanke, och en stark vilja att förklara nuet. Ammert föreslår därför att denna period, snarare än Englunds beteckning vetenskapligt

25 Kjeldstadli (1998), 260-62; Englund (1986a), 243, 387; Englund (1986b), 511, 575; Englund (2005), 291-304; Persson (2018), 92-116.

26 Ammert (2014), 58.

27 Jfr t.ex. hur Lorentzen (2005) i ett norskt sammanhang förlägger brottet till 1970-talet, 163-68, 227. Se också valet av kapitel-indelningen (1939-1979 respektive 1974-2013) i Skjelbred et. al. (2017).

28 Englund (1986b) 514-521; Persson (2018), 92-105; Anna Johnsson Harrie, Staten och läromedlen: En studie av den svenska statliga förhandsgranskningen av läromedel 1938-1991 (Linköping: Linköpings universitet, 2009), 216-18. Notera dock också hur det har påpekats att objektivitetsidealet under 1900-talets början sällan betraktades som något som stod i motsatsställning till ämnets fostrande ambitioner, samt hur kritik mot det senare förekom redan långt tidigare. Englund (1986a), 272-73, 288-93.

29 Englund (1986b), 491, 582-92; Persson (2018), 95-99, 105.

30 Persson (2018), 105.

31 Englund (1986b), 478-91, 511-74.

32 Henrik Åström Elmersjö, En av staten godkänd historia: Förhandsgranskning av svenska läromedel och omförhandling av historieämnet 1938-1991 (Lund: Nordic Academic Press, 2017), 140-41, $258-59,272-77$. 
rationell, bör kategoriseras som ideologiskt modernistisk..$^{33}$ Persson har argumenterat för hur denna närmast genealogisk ambition att förklara det egna samtida samhället (u55, lgr62, lgr 69), i seklets senare läroplansreformer (lgr80, lpo94) leder över i de skrivningar som kommit att förknippas med begreppet historiemedvetande. Istället för att som tidigare fostra till god samfundsanda, omdöme eller solidaritet, legitimeras skolämnet historias syfte nu med hänvisning till de metoder, färdigheter och förmågor som antas bidra till utvecklandet av en slags självständig handlingsberedskap. Kunskaper i historia framstod därmed inte längre som något fast och givet. Enligt Persson ger den senaste kursplanen (lgr11) fastmer uttryck för "historia som sanningsökande genom metaperspektiv utan färdiga svar". ${ }^{34}$

Det bör dock understrykas att både Ammert och Persson noterar en viss diskrepans mellan det historieämne som framträder i styrdokument respektive läromedel. De senare beskrivs, i flera avseenden, som mer konservativa. Exempelvis gör Persson klart att det på basis av innehållet i historieläroböcker inte går att hävda en utveckling där historia som erfarenhets- och livsvärld i vissa tider är tydligt starkare än historia som vetenskap. ${ }^{35}$ Denna beständighet över tid har också framhållits av andra. Staffan Selander pekar exempelvis särskilt på hur svenska läromedel i historia, under merparten av 1900-talet, fortsätter att deklarera ett slags sanna sakförhållanden; detta alltmedan mer kritiskt förhållningssätt genomgående tycks saknas. ${ }^{36}$

Sammantaget, går bilderna av hur det kunskapsideal som i olika avseenden kommit till uttryck i skolämnet historia under efterkrigstiden således delvis isär. Å ena sidan betonas en ökad elevcentrering och ett tilltagande fokus på vetenskaplighet; å andra sidan noteras tydliga drag av kontinuitet. Resultaten bygger dock företrädelsevis på analyser av läromedlens narrativa innehåll. Det torde således finnas starka skäl att också, närmare studera vilka former av kunskaper som efterfrågats i olika tider. ${ }^{37}$

\section{Frågor och övningar i historieläromedel - granskning, värdering och kritik}

På liknande sätt som i den internationella läromedelsforskningen i stort, så förekommer få utbildningshistoriska studier av frågor och arbetsuppgifter i historieläromedel. ${ }^{38}$ Några svenska forskare har visserligen, i små isolerade textsekvenser, uppmärk-

33 Niklas Ammert, Det osamtidigas samtidighet: Historiemedvetande i svenska historieläroböcker under hundra år (Lund: Lunds universitet, 2008) 82-85, 95, 105-10; Ammert (2014), 58-63.

34 Persson (2018), 92-116.

35 Persson (2018), 138, 150, 245-46. I jämförelse med real- och gymnasieskolans relativa fokus på kritiskt tänkande och distanserad analys, påpekar Persson dock att närhet, inlevelse och känsla (i synnerhet under 1960-talet) av tradition tillskrivits en starkare ställning i folk- och grundskolans styrdokument.

36 Selander (1998), 97. Jfr också: Persson (2019), 260 och det som beskriver som en konstaterande ansats i: Niklas Ammert, "Folkvilja, etikett eller jordbruksteknik?: En historiedidaktisk analys av synen på demokrati i historieläroböcker 1960-2003," Utbildning och demokrati 14, no. 3 (2005), 34.

37 Jfr Englund (2005), 132; Gustafsson (2017), 38. Valet av källmaterial kan dessutom motiveras med hänvisning till den forskning som på senare tid antytt att även läromedlens färdigtryckta uppgifter tycks ha omgärdats av en livlig kunskapsideologisk förhandlingsprocess. Åström Elmersjö (2017), 97-99.

38 Jfr diskussionen om läromedelsforskningens inriktning i Barbara Christophe et al. "New Directions," i The Palgrave Handbook of Textbook Studies, red. Eckhardt Fuchs och Annekatrin Bock (New York: Palgrave Macmillan, 2018), 420. Se dock enskilda undantag som t.ex: Sheri Berkeley et al., "Are History Textbooks More, "Considerate" After 20 Years?," The Journal of Special Education, 47, no. 4 (2014), 225. 
sammat den typ av källmaterial som ligger till grund för denna artikel. I inget fall används dock frågorna till mer än att styrka iakttagelser från texten i övrigt. ${ }^{39}$ Den engelskspråkiga forskning som riktats mot förtryckta arbetsuppgifter i läromedel i historia har företrädelsevis handlat om att värdera frågornas analytiska komplexitet. ${ }^{40} \mathrm{I}$ flera fall har dessa granskningar gjorts med utgångspunkt i Blooms klassiska taxonomi eller andra liknande klassificeringar. ${ }^{41}$ I en av det mest refererade av dessa studier har David B. LaVere, undersökt i vilken mån eleverna möter kognitivt mer utmanande uppgifter ju längre upp i skolsystemet de kommer. Han sammanfattar sina resultat i termer av oro:

The analysis revealed several problems. A disproportionate number of pedagogical exercises were recall-type questions. Many questions were very similar regardless of grade level. Some were ahistorical or failed to reflect high-quality content. ${ }^{42}$

Ett antal efterföljande studier har noterat liknande resultat. Från en rad olika länder vittnar forskare om avsaknaden av den typ av frågor som antas möjliggöra ett mer utvecklat historiskt tänkande. ${ }^{43}$ I vissa fall har dessa kritiska slutsatser inte bara genererats ur en analys av läromedlens frågor, utan också ur receptionsinriktade undersökningar av hur uppgifterna kan användas och uppfattas. ${ }^{44}$

39 Selander (1988) 76, 89; Ammert (2008) 114, 128, 130-31; Persson (2018) 197-98, 205. En studie delvis baserade på svenska arbetsuppgifter i mer samtida historieläromedel presenteras dock i: Niklas Ammert and Heather Sharp, "Working with the Cold War: Types of Knowledge in Swedish and Australian History Textbook Activities," Journal of Educational Media,Memory, and Society 8, no. 2 (2016).

40 Jfr Carl-Christian Fey och Eva Matthes, ”Textbook Quality Criteria and Evaluation,” i The Palgrave Handbook of Textbook Studies, red. Eckhardt Fuchs och Annekatrin Bock (New York: Palgrave Macmillan, 2018), 157-68.

41 Se t.ex. Rawadieh, Saleh Moh'd, "An Analysis of the Cognitive Levels of Questions in a Jordaniean Secondary Social Studies Textbook According to Bloom's Taxonomy" (Diss., Ohio University, 1998); LaVera (2008); Bulent Tarman och Burcin Kuran, "Examination of the Cognitive Level of Questions in Social Studies Textbooks and the Views of Teachers Based on Bloom Taxonomy," Educational Sciences: Theory \& Practice 15, no. 1 (2015); Bonnie B. Armbruster och Thomas H. Anderson, "What Did You Mean by That Question?: A Taxonomy of American History Questions," Technical Report No308, University of Illinois at Urbana-Champaign (1984), 213-22; Paul T. Boone, "Explicit Instruction in United States History Textbooks Exercises: The Role of Exercises in Navigating and Critically Evaluating Textbooks" (Diss. University of Nevada, 2010).

42 LaVere (2008), 3.

43 Berkeley et.al. (2014), 217-30; Lisbeth Bergum Johanson, ”The Norwegian Curriculum in History and Historical Thinking: A case study of three lower secondary schools," Acta Didactica Norge 9:1 (2015), 1-24; Basil Mackenzie och Carola Steinberg, "Recognising the Academic and Political Purposes Embedded in History Textbook Assessment Tasks," Yesterday and Today 14 (2015), 125-50; Kern E. Philgence, "A Comperative Schema Theory-Based Analysis of World History Print Textbooks and E-Textbooks," (Diss., Nortcentral University, 2017); Pranitha Bharath, "Analysing Historical Enquiry in School History Textbooks" (Diss., University of KwaZulu-Natal, 2018).

44 Janis M. Harmon, Wanda B. Hedrick och Elizabeth A. Fox, "A Content Analysis of Vocabulary Instruction in Social Studies Textbooks for Grades 4-8 ", The Elementary School Journal 100, no. 3 (2000), 253-271. Jfr Heather Sharp och Niklas Ammert, "Primary Sources In Swedish And Australian History Textbooks: A Comparative Analysis of Representations of Vietnam's Kim Phuc," International Journal of Historical Learning, Teaching and Research 14, no. 2 (2017); Ammert och Sharp (2016), 58-82; Basil Mackenzie, "Doing School History as Portrayed in Assessment Tasks Found in the European Expansion and Conquest in the 15th to 18th Centuries Units Contained in a Sample of Grade 10 South African CAPS-Compliant History Textbooks" (Diss., University of the Witwatersrand, 2015); Robert Thorp, "Representation and Interpretation: Textbooks, Teachers, and Historical Culture," IARTEM e-Journal 7, no. 2 (2015), 73-99. 
Istället för att granska huruvida läromedlens frågor möjliggör historiskt och kritiskt tänkande i en renodlat kognitiv mening, har bland andra Carla Van Boxtel undersökt hur nederländska elever responderar på två olika typer av inlevelsebaserade läromedelsfrågor. Den första typen påbjuder att eleven föreställer sig att den själv är en specifik historisk person. I den andra typen av fråga uppmanas eleven, såsom i den inledande emigrationsbrevsuppgiften, istället att söka rekonstruera vad en specifik eller abstrakt historisk aktör skulle kunna ha tänkt eller känt. Snarare än att utgå från sina egna erfarenheter så tycks dock flertalet elever, frågornas utformning till trots, basera sina svar på bokens information. ${ }^{45}$

I den här studien undersöks frågor och uppgifter i historieläromedel över tid. Detta görs dock inte med ambitionen att utvärdera huruvida det undersökta materialet är tillräckligt kognitivt utmanande. Undersökningen handlar inte heller om att pröva hur elever responderat på eller förstått olika typer av frågor. Avsikten är istället att undersöka de olika förhållanden mellan kunskaper om det förflutna och den i frågan tilltalade eleven, som påbjuds under en period som i tidigare utbildningshistoriska studier beskrivits i termer av en kunskapsideologisk kamp.

\section{Metod och material}

Källmaterialet i denna artikel baseras på frågor och arbetsuppgifter i tryckta historieläromedel. ${ }^{46}$ Det som undersökts är dock inte ett helt läromedelsbestånd. ${ }^{47}$ Sammantaget har 938 arbetsuppgifter och frågor valts ut. Frågorna är fördelade på 72 olika läromedel. Uppskattningsvis har ungefär lika många titlar sorterats bort i sökprocessen. ${ }^{48}$

Urvalet av material bygger på flera avvägningar. Böckerna som valts ut är utgivna mellan åren 1927-2015. ${ }^{49}$ Studiens fokus är emellertid i första hand riktat mot den period (1950-1993) som i tidigare forskning beskrivits i termer av en utbildningsideologisk dragkamp mellan en vetenskapligt rationell och en demokratisk utbildningskonception. Frågorna från mellankrigstiden, likväl som de allra senaste läroböckernas exempel på uppgifter, har främst använts för att sätta den huvudsakliga undersökningsperioden i ett större sammanhang.

45 Tessa de Leur, Carla Van Boxtel och Arie Wilschut, "'Just Imagine ...': Students' Perspectives on Empathy Tasks in Secondary History Education," International Journal of Historical Learning, Teaching and Research 13, no. 1 (2015), 69-84.

46 Som frågor, övningar och arbetsuppgifter har det räknats som i läromedlen formulerats för att besvaras eller genomföras av eleven. I själva läromedelstexten invävda retoriska frågor har inte beaktats.

47 Urvalet omfattar de mest spridda titlarna från respektive tidsperiod. Jfr Gustafsson (2017), 69-77.

48 Vissa läromedel, i synnerhet i början och slutet av undersökningsperioden, har antingen helt saknat frågor, eller så har de omfattat en annan innehållslig tematik än den efterfrågade

49 De använda läromedlen finns kronologiskt angivna i källförteckningen. 
Tabell 1. Urval av läroböcker och antalet frågor (n); antal totalt, respektive innehållslig kategori

\begin{tabular}{|c|c|c|c|c|c|}
\hline & \multirow{2}{*}{$\begin{array}{c}\text { Antal } \\
\text { böcker }\end{array}$} & Totalt & Arabriket & Gustav II Adolf & Emigrationen \\
\hline$(1927)$ & 1 & 132 & 0 & 127 & 5 \\
\hline $1950-1961$ & 16 & 63 & 6 & 50 & 7 \\
\hline $1962-1968$ & 11 & 166 & 19 & 96 & 51 \\
\hline $1969-1979$ & 22 & 177 & 25 & 81 & 71 \\
\hline $1980-1993$ & 7 & 152 & 69 & 65 & 18 \\
\hline$(1994-2015)$ & 15 & 248 & 40 & 143 & 65 \\
\hline $1927-2015$ & 72 & 938 & 159 & 562 & 217 \\
\hline
\end{tabular}

Materialet har både i urvals- och analysprocessen i huvudsak ordnats med hänsyn till de läroplansskiften som förekommit under denna tid. ${ }^{50}$ Att undersöka alla uppgifter som förekommer i de 72 läromedlen låter sig inte göras inom ramen för denna artikel. För att skapa ett för den teoretiska inramningen tillbörligt underlag, har jag istället valt att undersöka de frågor som applicerats på det tidigmedeltida Arabriket (159 st), händelserna runt Gustav II Adolf och trettioåriga kriget (562 st) och/eller 1800-talets svenska emigration till Amerika (217 st). ${ }^{51}$

Det vidare analysarbetet kan beskrivas som en process i flera steg. I ett första skede har alla de drygt niohundra frågorna samlats i en gemensam lista. Därefter har jag, genom upprepad läsning, såväl kronologiskt som tematiskt, sökt identifiera den typ av skillnader i frågornas form som har bäring på artikelns övergripande syfte. Fem sådana dimensioner har noterats. Samtliga frågor har därmed kodats med avseende på:

1) ... det efterfrågade svaret framstår som givet på förhand (sluten fråga), eller där det synes finnas utrymme för eleven att utforma svaret på flera olika sätt (öppen fråga),

2) ... de påbjuder svar som förutsätter att eleven med stöd av kunskaper om det historiska sammanhanget gör egna analyser av historiska förlopp eller tolkar och drar egna slutsatser utifrån historiskt källmaterial (disciplinärt analytiska frågor),

3) ... de påbjuder svar som föreskriver att eleven söker leva sig in i andras situation, (inlevelsebaserad fråga),

4) ... de påbjuder svar som förutsätter att dåtidsförhållanden relateras till elevens egen samtid? (samtidsorienterad fråga),

5) ... de påbjuder svar som inrymmer estetiska arbetsformer som att rita, modellera eller dramatisera.

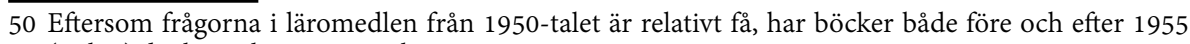
(upl55) dock samlats i samma kategori.

51 Detta urval bygger på ett försök att välja frågor som traditionellt kretsar runt perioder som i tur och ordning förknippats med nationell patriotism och storhet, fattigdom och misslyckande samt det orientaliskt främmande. Jfr Tingsten (1969). 
De fem koderna är potentiellt överlappande. Exempel på kodning ges i figur 1 nedan.

\begin{tabular}{|c|c|c|c|c|c|}
\hline & 1 & 2 & 3 & 4 & 5 \\
\hline & $\begin{array}{l}\text { Öppen (ö)/ } \\
\text { stängd (s) }\end{array}$ & $\begin{array}{c}\text { Samtids- } \\
\text { orienterad (x) }\end{array}$ & $\begin{array}{l}\text { Inlevelse- } \\
\text { baserad (x) }\end{array}$ & $\begin{array}{l}\text { Estetiska arb. } \\
\text { former }(\mathrm{x})\end{array}$ & $\begin{array}{l}\text { Disciplinärt } \\
\text { analytisk }(\mathrm{x})\end{array}$ \\
\hline $\begin{array}{l}\text { Vad kallades } \\
\text { Muhammeds } \\
\text { efterträdare? }\end{array}$ & $\mathrm{s}$ & & & & \\
\hline $\begin{array}{l}\text { Låtsas att du är en } \\
\text { utvandrare. Gör } \\
\text { tillsammans med } \\
\text { năgra av dina kam- } \\
\text { rater en pjäs som } \\
\text { skildrar er resa till } \\
\text { Amerika }\end{array}$ & ö & & $\mathrm{x}$ & $\mathrm{x}$ & \\
\hline $\begin{array}{l}\text { Känner du till } \\
\text { exempel på hat och } \\
\text { våld, som religiösa } \\
\text { motsättningar } \\
\text { skapat i vår egen } \\
\text { tid? }\end{array}$ & $\ddot{o}$ & $\mathrm{x}$ & & & \\
\hline $\begin{array}{l}\text { Jämför böndernas } \\
\text { ställning i Danmark } \\
\text { och Norge }\end{array}$ & ö & & & & $\mathrm{x}$ \\
\hline
\end{tabular}

Figur 1: Illustration av kodning av frågor

Då materialet i flera avseenden ändrar karaktär över tid, framstår det som vanskligt att lägga alltför stor betydelse vid olika frågetypers kvantitativa förekomst över tid. Istället för att enbart räkna frågeformer i termer av frekvens (se tab. 2-4), har det slutliga analysarbetet således framförallt ägnats åt att - med avseende på var och en av dessa fem dimensioner - mer kvalitativt, och med stöd av den inledningsvis anförda besöksmetaforen, söka tolka vilka olika förhållanden mellan kunskaper om det förflutna och den i frågan tilltalade eleven, som kommer till uttryck i olika tider. I denna tolkningsprocess har jag framförallt återvänt till de olika sätt att närma sig den andre som genusvetaren Lisa Disch formulerat i nära dialog med sin egen läsning av Arendts besöksmetafor. ${ }^{52}$

Utöver besöket, så diskuterar Disch vad som skulle kunna beskrivas som turistens, kolonisatörens och hemmasittarens förhållningssätt. Om den senare helt stannar hemma i sin egen invanda miljö, gör de båda förra en slags resor som aldrig fullt ut blir till ett arendtskt besök. Översatt till förhållandet elev och skolämnet historia kan kolonisatörens möte med de historiska berättelserna sägas präglas av att det $\mathrm{i}$ alltför hög grad sker på basis av den samtida betraktarens egna behov, åsikter och intressen. Turisten däremot, intresserar sig tvärtom enbart just för det särskiljande. Den iakttar distanserat det (historiskt) främmande, men söker aldrig relatera det till sina egna personliga erfarenheter. ${ }^{53}$

52 Se åter Persson [under publ] 2019.

53 Jfr. Lisa J. Disch, Hanna Arendt and the Limits of Philosophy (New York: Cornell University Press, 1994), 146-72; Lisa Disch, "'Please Sit Down, but Don't Make yourself at home': Arendtian 'Visiting' and the Prefigurative Politics," i Hanna Arendt \& the meaning of politics, red. Craig Calhoun och John McGowan (University of Minneapolis: Minnesota Press, 1997), 132-65. 


\section{Arbetsuppgifter i svenska läromedel i historia}

Flertalet av de svenska läroböcker i historia som gavs ut under mellankrigstiden saknar arbetsuppgifter och frågor. De senare upplagorna av Grimbergs klassiska Sveriges historia för folkskolan utgör i detta avseende undantag. I 1927 års upplaga förekommer exempelvis 132 frågor som svarar mot det innehåll som utgjort grund för denna artikel. 125 av dessa uppgifter rör tiden runt Gustav II Adolf. Frågornas innehåll genomsyras tydligt av den nationalism som i tidigare forskning förknippats med skolämnet historias utformning vid denna tid. Elevens uppdrag är ofta att deklarera vem som krigade mot vem, att ange när krig började och slutade, samt att beskriva kungens och andra fältherrars egenskaper.

Vilka egenskaper hade uppfostran givit honom? [Gustaf II Adolf]

Vilka voro de förnämsta svenska härförarna?

Vilken var Gustaf Adolfs mest lysande tid? Nämn något som visar detta! ${ }^{54}$

Uppgifterna tycks genomgående formulerade med ambitionen att väcka förundran och förtjusning inför något bländande och storartat. Formen på frågorna ger dock begränsat utrymme för eleven att själv utforma sina svar. Historien återfinns i texten. Svaren på frågorna finns redan framskrivna i bokens berättelser. Det senare är emellertid inget specifikt för Grimbergs lärobok. Tvärtom är det slående hur även efterkrigstidens uppgifter allt som oftast tycks påbjuda svar som handlar om att reproducera en redan färdigförhandlad beskrivning av vad som har varit.

\section{Likt en turist $i$ en avlägsen, och av andra redan på förhand färdigtolkad för- flutenhet}

Möjligheten att svara rätt på mer än ett sätt framstår som mycket begränsad i drygt tre fjärdedelar av de frågor som undersökts inom ramen för denna studie. Med viss variation gäller detta oavsett vilket område frågorna handlar om, och när de är skrivna. ${ }^{55}$

Tabell 2. Andel slutna frågor (\%). Källa: Se de 72 st läromedel som listas i källförteckningen

\begin{tabular}{|c|c|c|c|c|c|}
\hline & \multicolumn{5}{|c|}{ Slutna frågor (\%) Läromedel i historia 1928-2015 } \\
& Arabriket & Gustaf Adolf & Emigrationen & Totalt (\%) & $(\mathrm{n} / \mathrm{N})$ \\
\hline 1927 & - & 97 & 80 & 96 & $127 / 132$ \\
\hline $1950-1961$ & 60 & 58 & 60 & 56 & $35 / 63$ \\
\hline $1962-1968$ & 84 & 70 & 77 & 74 & $123 / 166$ \\
\hline $1969-1979$ & 96 & 80 & 94 & 87 & $154 / 177$ \\
\hline $1980-1993$ & 72 & 85 & 61 & 78 & $118 / 152$ \\
\hline $1994-2015$ & 71 & 63 & 57 & 61 & $152 / 248$ \\
\hline $\mathbf{1 9 2 7 - 2 0 1 5}$ & 78 & 77 & 76 & 76 & $685 / 938$ \\
\hline
\end{tabular}

54 Carl Grimberg, Sveriges historia för folkskolan (Stockholm: P.A. Norstedt \& söner, 1927), 210-11.

55 Med andra ord ligger andelen på ungefär samma nivå som noterats i internationella studier av samtida läroböcker. Jfr t.ex. Rawadieh (1998), 77; LaVere (2008) 5-6; Boone (2010), 56, 67; Mackenzie (2015), 74; Mackenzie och Steinberg (2015); Tarman och Kuran (2015), 135-36, 219; Philgence (2017), 122, 129. 
I motsats till vad som skulle kunna antas vid en läsning av de enskilda kursplanerna är det följaktligen svårt att hävda att graden av öppenhet i frågorna skulle öka över tid. Faktum är att den lägsta andelen slutna frågor faktiskt härrör från perioden 1950-1962. Denna beständighet över tid gäller även i flera avseenden frågornas utformning. Under hela efterkrigstiden förväntas nya generationer av elever upprepa ord, namn och årtal som redan nämnts i löptexten. ${ }^{56}$ Lika väl som det i 1960-talets läromedel riktas uppmaningar om att göra förteckningar av alla freder från Gustav Vasa till Karl X Gustav ${ }^{57}$ och att ange under vilka år som det trettioåriga kriget varade $^{58}$; lika väl förekommer de fyrtio år senare liknande anvisningar om att återge vad som hände den 6 november $1632^{59}$ och att redogöra för i hur många år drottning Kristina regerade. ${ }^{60}$ I frågan nedan från 1996 är det arabernas krigföring som är i fokus:

Vilka områden erövrades under den första anfallsvågen? Under den andra? När och var stoppades araberna? ${ }^{21}$

En av de minst öppna typerna av uppgifter handlar i dessa sammanhang om att fylla i enskilda specifika ord i textluckor.

År ... landsteg Gustav II Adolf i .... En av hans officerare var Gustav .... Hans familj var med. Dottern Agneta berättar om denna krigiska tid i en .... Senare följde hon sin man till kriget i Tyskland. Vägarna var som en .... och .... Många byar hade... under kriget och hela.... hade flytt. ${ }^{62}$

Samtliga av de luck-text-uppgifter som lokaliserats återfinns i läromedel utgivna mellan åren 1966-1976. 1970-talet (och tiden för läroplanen Lgr69) är överhuvudtaget tveklöst den period efter andra världskriget när flest frågor, nästan 90 procent, kategoriserats som slutna. Denna kulmen kan rimligtvis delvis förstås mot bakgrund av den tidens starka tilltro till läromedel som teknik. ${ }^{63}$

Inte heller påståendet att skolämnet historia skulle ha genomgått en allmän förskjutning, till förmån för mer vetenskaplig analys, kan sägas styrkas av det undersökta materialet. ${ }^{64}$ I tabellen 3 nedan illustreras förekomsten av frågor som inleds med ordet

56 Se tabell 2. Notera t.ex. hur läromedlen från perioden 1950-1961 tvärtom uppvisar lägst andel stängda frågor (58\%).

57 Axel Hagnell och Gunnar Olander, Svensk och allmän historia för enhetsskolans mellanstadium (Gävle: Skolförlaget Gävle AB, 1960), 160.

58 Björkblom, Dusing och von Horn (1963), 172.

59 Ingrid Åsgård och Lars Hildingsson, Levande historia - Studiebok årskurs 6 (Stockholm: Natur och kultur: 1999), 8.

60 Elisabeth Ivansson och Mattias Tordai, Historia: SO.S, del 2 av fyra (Stockholm: Almqvist \& Wiksell, 2003), 39.

61 Bengt Almgren, Hans Thorbjörnsson och Hans Tillman, Historia 1: En lärobok för grundskolans senare del, SO Direkt, (Stockholm: Bonniers utbildning, 1996), 131.

62 Alf Åberg, Lennart Husén, Hugo Serdén och Karl Gustav Thorén, Ur folkens liv: Läsebok i historia för femte årskursen (Stockholm: Natur och kultur, 1976), 61.

63 Se diskussionen om behavioristisk undervisningsteknologi (och MUT 1972-1975) i: Englund 1986b, 492-97, 582-99.

64 Jfr avsnittet om tidigare forskning och det som betecknas som en explanativ ansats i: Ammert (2005), 34. 
varför (varför-frågor), uppgifter som handlar om att eleven med på basis av historiska kunskaper och/eller autentiskt källmaterial själv förväntas rekonstruera ett historiskt förlopp (rekonstruera), samt frågor som tydligt öppnar för en typ av analys där slutledningen alls inte kan antas vara på förhand given (öppet analytiska).

Tabell 3. Antal analytiska frågor (n). Källa: Se de 72 st läromedel som listas i källförteckningen

\begin{tabular}{|c|c|c|c|c|}
\hline \multirow{2}{*}{} & \multicolumn{5}{|c|}{ Analytiska frågor (n) } \\
& Varför-frågor & Rekonstruera & Öppet analys & $(\mathrm{N})$ \\
\hline 1927 & 9 & - & 2 & 132 \\
\hline $1950-1961$ & - & 5 & 9 & 63 \\
\hline $1962-1968$ & 11 & 7 & 2 & 166 \\
\hline $1969-1979$ & 28 & 1 & 9 & 177 \\
\hline $1980-1993$ & 23 & 6 & 13 & 152 \\
\hline $1994-2015$ & 37 & 25 & 13 & 248 \\
\hline $1927-2015$ & 108 & 44 & 48 & $/ 938$ \\
\hline
\end{tabular}

Även i dessa fall är spridningen relativt jämt fördelad under efterkrigstiden. Varför-frågan verkar visserligen få rejält fäste i läromedlen först i början av 1970talet. Tidigt ute är i detta avseende en av de många upplagorna av läromedlet Ur folkens liv, från 1971:

\footnotetext{
Varför ingrep Gustaf II Adolf i religionskriget mellan protestanter och katoliker? [---]

Varför ville inte adelsmännen att det skulle hållas riksdag i Stockholm 1650? [---]

Varför blev vissa pojkar soldater? ${ }^{65}$
}

Även om nästan en femtedel av frågorna efter 1970 innehåller ordet varför, så svarar de emellertid oftast mot relativt självklara avsnitt i lärobokstexten. I denna mening skulle dessa varför-frågor således kunna sägas ha en liknande repetitiva karaktär som merparten av de övriga frågorna. Ordvalet till trots, så tycks det sällan vara eleverna som förväntas göra egna analyser av ett historiskt problem. Svaret - orsakerna och följderna - finns redan tydligt framskrivna i lärobokstexten; de behöver bara återfinnas och återges. ${ }^{66}$

Bland de mer öppna analysfrågor som trots allt förekommer över tid märks enbart några få exempel som tydligt påbjuder ett slags vetenskapligt underbyggt resonemang.

65 Torsten Eklund et.al., Ur folkens liv: Lärobok i historia åk 6 (Stockholm: Natur och Kultur, 1971), 18. 66 Åsgård och Hildingsson (1999), 6, 11. Exempel på motsatsen syns dock i: Erik Nilsson, Hans Olofsson och Rolf Uppström, Hi: Historia 7-9, Utkik (Malmö: Gleerups, 2013). Jfr liknande resonemang i Persson (2018), 205. 
Redan före införandet av läroplanen Lgr62 går det visserligen att notera några sällsynta uppmaningar att jämföra. ${ }^{67}$ I läromedel från 1990-talet märks därtill, en slags dualistiska frågor av typen: "Sverige både vann och förlorade slaget i Lützen. Varför kan man säga så?”. ${ }^{6}$ Därutöver förekommer dock såsom framgår av tabell 3, de mer kognitivt utmanande och därmed också mer öppna vetenskapligt analytiska frågorna anmärkningsvärt sällan.

När det gäller arbetet med källor och källkritik, bör det framhållas hur det under 1960-talet börjar dyka upp en särskild genre av källtextböcker. Dessa innehåller dock långtifrån alltid förtryckta frågor och övningar. Det gör däremot de studie- och arbetshäften som produceras under 1970- och 1980-talet. De senare har närmast karaktären av övningsböcker. De innehåller allt ifrån korsordsflätor, rikligt illustrerade bilder med pratbubblor och historiska artefakter, till ibland; korta historiska källor såsom exempelvis brev, dagboksutsnitt eller historisk statistik. ${ }^{69}$

Det bör dock understrykas att de rekonstruerande kunskapsideal som vanligtvis förknippats med senare styrdokument inte heller är helt frånvarande i de tidiga läromedlen. Redan i Historia för folkskolan, från 1956, förekommer exempelvis uppmaningar om att gruppvis göra egna "arbetshäften" ${ }^{70}$ Några år senare föreslås det bland annat att eleverna ska, ta reda på om någon i den egna släkten emigrerat till USA, samla information om någon stad och reflekterar över om stadsvapnet säger något om dess historia, eller - som i fallet nedan - undersöka huruvida det i den egna sockenkyrkan finns föremål som rövats nerifrån Europa: ${ }^{71}$

Läs [---]. Anteckna under läsningen några föremål som fördes hem till Sverige från
främmande länder. Sök efter bilder av dessa föremål och rita av dem. Skriv också korta
förklaringar till hur de användes m.m. Fördela arbetet inom gruppen. Undersök om
det finns "rövade skatter" från storhetstiden i din hemtrakt. Kanske kyrkan har något
föremål, som skänktes av en adelsman. ${ }^{72}$

Denna typ av efterforskande, och ibland också historiebruksrelaterade, uppgifter framstår emellertid som jämförelsevis avancerade. Över hela den undersökta perioden är det (se åter tabell 3) snarare noterbart få frågor som kräver något annan än att upprepa en redan färdigförhandlad, beskrivning av vad som har varit. ${ }^{73} \mathrm{De}$, liksom merparten av de övriga frågor som beskrivits ovan, påbjuder därmed en form av kunskap som främst handlar om att reproducera ett i sig självt givet innehåll.

67 Jfr t.ex. uppgiften att jämföra adelns och böndernas "ställning i Sverige och Danmark" i Hagnell och Olander (1960), 160.

68 Berit Thorén, Karl-Gustav Thorén Alf Åberg, Läsebok i historia 4: Stormaktstiden (Stockholm: Natur och kultur, 1991), 21; Nilsson, Olofsson och Uppström (2013). Jfr också Ivansson och Tordai (2003), 39.

69 Jfr även beskrivningen av framväxten av det Englund, utifrån argumenten individualisering och rationalisering, beskriver som undervisningsteknologi: Englund (1986b), 430-33, 492-510.

70 Helge Haage och Sven Wikberg, Historia för folkskolan: Del 2 Sjätte och sjunde (åttonde) skolåren (Stockholm: Natur och kultur, 1956), 241.

71 Ture Casserberg och Göte Rudvall red. Ur svenska historien 3: Grundskolans läsebok (Stockholm: Svenska bokförlaget Nordstedts, 1965), 226; Björkblom, Dusing och von Horn (1963), 158.

72 Björkblom, Dusing och von Horn (1963), 168.

73 Som ett tydligt undantag notera dock de amerikabrevbaserade källövningarna i: Jan-Olof Fallström, Lars Hildingsson och Göran Wadner, Levande historia: Läsebok 2, (Stockholm: Natur och kultur, 1990), 182. 
På motsvarande sätt som diskuteras i tidigare internationell forskning märks däremot jämförelsevis få frågor som lämnar utrymme för eleven att själv använda sina referenskunskaper till att resonera runt mer öppet formulerade problemställningar. ${ }^{74}$

\section{Inlevelse och tyckande - en varsam besökare eller brutal kolonisatör?}

Alla frågor i det undersökta materialet är dock inte lika slutna. Under hela perioden förekommer också uppgifter där svaren inte framstår som helt på förhand givna. ${ }^{75}$ Redan i metodkapitlet noterades ett antal sådana frågor som mer aktivt bjuder in eleven att delta i utformningen av svaret. I tabell fyra anges förekomsten av frågor som fodrar svar som inrymmer estetiska arbetsformer som att rita, modellera eller dramatisera, som påbjuder att eleven sätter sig in en annan (historisk) persons situation (rolltagande), och/eller som förutsätter att dåtidsförhållanden relateras till elevens egen samtid (samtid). Eftersom dessa elevinvolverande uppgifter är relativt få, bör de kvantitativa förändringarna över tid hanteras särskilt varsamt.

Tabell 4. Antal elevinvolverande frågor (n). Källa: Se de 72 st läromedel som listas i källförteckningen

\begin{tabular}{|c|c|c|c|c|c|}
\hline & \multicolumn{5}{|c|}{ Elevinvolverande frågor (n) } \\
& Estetiska arbf. & Rolltagande & Samtid & Åsikter & $(\mathrm{N})$ \\
\hline 1927 & 0 & 0 & 0 & 0 & 132 \\
\hline $1950-1961$ & 6 & 6 & 1 & 0 & 63 \\
\hline $1962-1968$ & 33 & 10 & 3 & 1 & 166 \\
\hline $1969-1979$ & 3 & 7 & 4 & 8 & 152 \\
\hline $1980-1993$ & 10 & 3 & 8 & 5 & 248 \\
\hline $1994-2015$ & 20 & 31 & 9 & 32 & $/ 938$ \\
\hline $1927-2015$ & 72 & 57 & 25 & 46 & \\
\hline
\end{tabular}

I de flesta fall förekommer dessa sällsynta uppmaningar emellertid utspridda i läromedel utgivna under hela efterkrigsperioden. Redan i Vår historia från 1952, figurerar följaktligen frågor som lämnar större utrymme åt eleven att själv utforma sitt svar. ${ }^{76} \mathrm{De}$ mer eller mindre uttalade försöken att involvera eleverna ser lite olika ut. I några få fall handlar det om att explicit bjuda eleven att själv välja innehåll efter intresse:

Återberätta i en uppsats något i texten som särskilt har intresserat dig. Hitta själv på rubrik. Illustrera gärna.[---] Utarbeta underrubriker till något av kapitlets stycken försök att i varje stycke finna det viktigaste. [---] Välj ut ett stycke i kapitlet att skriva frågor till. Byt frågorna med en kamrat och besvara dem skriftligt. ${ }^{77}$

74 Jfr t.ex. Rawadieh (1998), 77; LaVere (2008) 5-6; Boone (2010), 56, 67; Mackenzie (2015), 74; Mackenzie och Steinberg (2015); Tarman och Kuran (2015), 135-36, 219; Philgence (2017), 122, 129.

75 Se åter tabell 2.

76 Yngve Berg, Vår historia: II Nya tiden (Stockholm: Almqvist \& Wiksell, 1952), 50, 68, 72.

77 Tham (1963), 217, 198, 184. 
I andra fall uppmanas eleven att jämföra det den läst om med liknande företeelser i den egna samtiden. I exemplet nedan är uppdraget att i pjäs-form jämföra 1600-talet matvanor med dagens.

Vad man åt och drack i en soldatfamilj. Spela en pjäs där ni jämför matvanor förr och nu. Börja t.ex. med att "Förrson" berättar om hur man förvarade kött, fläsk mm på hans tid, och "Nuson" talar om hur man gör i våra dagar. Ni kan tala om fisk, bröd, smör, öl, grönsaker, kryddor, ölbryggning, kaffe och tobak. ${ }^{78}$

Även i detta avseende är utfallet ett annat än vad som skulle kunna ha förväntats. Den förändring som i tidigare forskning formulerats som en modernistisk vändning mot samtiden, får inget starkt genomslag i de undersökta frågornas form. ${ }^{79}$ Den i medeltidsavsnittet insprängda frågan om samtida arabisk nationalism, är i detta sammanhang tämligen sällsynt:

Vilka länder behärskas i våra dagar av den arabiska nationalismen? Hur tar denna sig uttryck. Skriv en kort redogörelse. ${ }^{80}$

Utöver de fåtaliga anmaningarna om att rikta frågan mot händelser och fenomen i samtiden går det därtill också att urskilja en typ av till synes lite vanligare frågor som relaterar till elevernas egen föreställningsförmåga. Många gångar anknyter även dessa arbetsuppgifter till estetiska uttrycksformer. Redan i läromedel från början av 1950-talet åläggs eleven att använda den egna fantasin för att "rita" historiska scenerier. ${ }^{81}$ Under tiden för Lgr 62 utgör dessa bildskapande uppgifter nästan en femtedel av de undersökta frågorna. ${ }^{82}$ Elevernas förväntas bland annat teckna egna bilder av vasaborgar, segelfartyg, postryttare och nybyggarstugor, eller som i fallet nedan, att göra utställningar av bilder ur veckotidningar och gamla skolradiohäften:

Samla bilder till vasatiden och ordna en utställning av bilderna. Klassen kan gärna dela med sig i två lag och tävla om vilket lag som finner de flesta och bästa bilderna. Sätt upp bilderna med häftstift på en fiberplatta. I veckotidningar, gamla skolradiohäften och dagstidningar finns säkert bilder som passar. Obs.! Böcker får inte klippas sönder! ${ }^{83}$

Läromedlen från 1950- och 1960-talen uppmanar dock inte bara eleverna att rita, skriva dikter och sånger, ${ }^{84}$ de förväntas också använda sin fantasi till att bygga egna modeller över alltifrån marknadsplatser och gruvor, till tåget över Bält:

78 Karl-Gustav Thorén och Torsten Eklund, Studiehäfte: Ur folkens liv åk 5 (Bokförlaget Natur och Kultur: Stockholm, 1972), 23.

79 Jfr Ammert (2014), 58-63. Däremot går det att notera en förskjutning i frågornas innehåll (t.ex. från politisk, till social- och kvinnohistoria).

80 Leif Dannert och Waldemar Lendin, Historia för enhetsskolans högstadium 2: Årskurs 9 (Stockholm: Almqvist \& Wiksell/Gebers förlag, 1961).

81 Berg (1952).

82 Se tabell 4. Noteras bör att de flesta av dessa frågor är kopplade till Gustav II Adolf, och nästan ingen till arabriket.

83 Berg (1952), 73-74.

84 Björkblom, Dusing och von Horn (1963), 157; Tham (1963), 217. 
Bygg en modell av Tåget över Bält i sandlådan. Använd t.ex. glas till is. Tennsoldater kan användas, men teckningar av härar städer m.m. duger bra. Gör modellen så stor att man ser delar av Sverige och Tyskland också. ${ }^{85}$

I vissa fall anspelar uppgifterna än mer explicit på elevernas inlevelseförmåga. Redan i 1950-talets läromedel artikuleras en önskan om att eleverna ska föreställa sig historiska företeelser. Exempelvis anmanas elever att beskriva "sina intryck". ${ }^{86}$ Senare märks också en typ av frågor där de uppmanas att inta en specifik roll. Ett tidigt och återkommande tema kretsar runt uppgiften att rekonstruera och gestalta ett samtal mellan två soldater på väg ner till kriget i Nordeuropa ${ }^{87}$ Uppgiften "Med vagn i Trettioåriga krigets Tyskland" handlar exempelvis om att eleven, med inlevelse, förväntas berätta om kriget i termer av skräck, smuts och plågor. ${ }^{88}$ I slutet av 1990-talet förekommer på motsvarande sätt upprepade uppmaningar om att föreställa sig enskilda soldaters olika umbäranden:

Låt en general i Gustaf Adolfs armé berätta varför svenskarna segrade vid Breitenfeldt. [---] Vad tror du de män tänkte som fick order att gå över isen på Lilla Bält? [---] Låtsas att du är en soldat i trettioåriga kriget. Du skriver ett brev hem till dina släktingar. Vad berättar du? [---] Om modern teknik, radio och TV hade funnits på plats i Lützen den 6 november 1632, hur hade då direktrapporten om kungens död sett ut i text, tal och bild? Man hade säkert intervjuat Axel Oxienstierna. Vad tror du han skulle ha sagt? Skriv och dramatisera. ${ }^{89}$

I andra fall går dessa inlevelseorienterade uppgifter istället ut på att inta rollen av en specifik historisk person, såsom Johan Gyllenstierna $\mathrm{a}^{90}$, Axel Oxenstierna ${ }^{91}$, Gustav II Adolf eller Agneta Horn ${ }^{92}$. För att tydliggöra att uppgiften tar sin utgångspunkt i elevens föreställningsvärld förekommer återkommande formuleringar såsom: "Låtsas!", "Tänk dig, "vad tror du", eller till och med "hur känner du dig":

Uppe i kyrktornet står socknens kyrkoherde och ser på mönstringen. Vad tror du att han tänker på??3

Tänk dig att du blev uttagen som soldat och får chansen att skriva ett brev hem till din familj. Skriv och berätta om soldatlägret, de andra pojkarna som blev uttagna i din hemby, landet ni marscherar genom, människorna ni ser, hur känner du dig. ${ }^{94}$

85 Björkblom, Dusing och von Horn (1963), 179.

86 Vilhelm Tham red., Historien och samhället: Del I: Läro- och läsebok $i$ allmän och svensk historia samt samhällskunskap (Stockholm: AVCarlssons Bokförlag AB, 1950), 217. Jfr även t.ex. Ragnar Wirsén, Historia för enhetsskolan: Del 1. Mellanstadiets kurs (Stockholm: Svenska bokförlaget Norstedts, 1959), 150.

87 Ragnar Wirsén, Historia för folkskolan (Stockholm: Svenska bokförlaget/Norstedts, 1955), 160; Ragnar Wirsén och Karl Meurling, Historia för grundskolan årskurs 4-6 (Stockholm: Svenska bokförlaget Norstedts, 1963), 215.

88 Åberg et al. (1976), 61.

89 Åsgård och Hildingsson (1999), 7, 11, 16.

90 Björkblom, Dusing och von Horn (1963), 168.

91 Eklund et al. (1971), 28.

92 Åsgård och Hildingsson (1999), 11, 16.

93 Åsgård och Hildingsson (1999), 18.

94 Ivansson och Tordai (2003), 39. 
Istället för att försöka göra ett arendtskt besök i historien, så förefaller referenskunskaper om det förflutna i dessa senare fall närmast kunna förstås som något sekundärt. Utan uttalade krav på att ta någon som helst hänsyn till det historiska sammanhanget, så förespeglas eleverna att historisk kunskap kan likställas med att se situationen ur historiska aktörers egna ögon. Endast undantagsvis förekommer inlevelsebaserade frågor som, såsom i fallet nedan, explicit påbjuder den dubbla tankeoperation som i den här artikelns inledning förknippades med metaforen att gå på besök hos den andre.

Många unga svenskar flyttade till Amerika, men ännu fler valde att stanna kvar. Tror du att du själv hade flyttat, om du vuxit upp i en svensk by i slutet av 1800-talet? Förklara varför du svarar som du gör. ${ }^{95}$

Även om det över tid tycks bli allt färre uppgifter som handlar om att rita och att bygga modeller (se åter tab. 4), så uppvisar det undersökta materialet således återkommande exempel där eleverna förväntas att använda sin fantasi för att sätta sig in i någon annans situation. Det sätt på vilket detta förväntas iscensättas, utformningen av uppgifterna, verkar dock delvis förändras över tid. Mot slutet av 1970-talet, och framförallt i flera av böckerna från 1990-talet, dyker det upp allt fler explicita uppmaningar om att formulera egna åsikter. ${ }^{96}$ Eleverna förväntas bland annat tycka till om, drottning Kristinas tronavträdelse, 1600-talets namngivningsskick, eller (som i de båda fallen nedan) att hysa en åsikt om huruvida Sverige bör lämna tillbaka de krigsbyten som rövades hit under 1600-talet:

Ska Sverige behålla eller lämna tillbaka sina krigsbyten från 1600-talet? Vad tycker du? ${ }^{97}$

Då och då kommer önskemål om att Sverige skall lämna tillbaka en del krigsbyten. Så har också skett ibland. [---] Skall Sverige lämna tillbaka sina krigsbyten? Vad tycker $\mathrm{du} ?^{98}$

Dessa åsiktsdeklarerande uppmaningar tycks således främst påbjuda svar som handlar om att eleven förväntas formulera en individuell uppfattning. Däremot kombineras uttrycket - vad tycker $d u$ ? - sällan med explicita instruktioner om att dessa personliga åsikter behöver motiveras eller understödjas med hänvisningar till kunskaper om historiska sakförhållanden. I frågan nedan är det arabernas erövringar som skall värderas:

Vad anser du om att sprida en religion med våld ${ }^{99}$

95 Nilsson, Olofsson och Uppström (2013), 217.

96 Se åter tabell 4. Jfr t.ex. tydligt i Torsten Eklund, Lars Hildingsson, Lennart Husén, Karl-Gustav Thorén och Alf Åberg, Ur folkens liv 2: Historia för mellanstadiet, grundbok (Stockholm: Bokförlaget Natur och Kultur AB, 1978); Thorén, Thorén och Åberg (1991). Jfr liknande iakttagelse i Persson (2018), 197.

97 Eklund et al. (1978), 67.

98 Thorén, Thorén och Åberg (1991), 43.

99 Almgren, Thorbjörnsson och Tillman (1996), 131. 
Om uppgifterna inte svarar mot enskilda textsekvenser i lärobokstexten, tycks de därtill under de senare decennierna istället hänvisa eleven till den nästan spekulativa uppmaningen: Vad "tror du"? ${ }^{100}$

\author{
Varför tror du att pojkarna bytte namn, när de började studera? ${ }^{101}$ \\ Varför växte städerna, tror du? ${ }^{102}$ \\ Hur tror du nybyggarna såg på indianerna? ${ }^{103}$
}

Då dessa uppmaningar om att tycka och tro inte förknippas med vidare påstötningar om att motivera de egna slutledningarna, så framstår det närmast som om det som primärt efterfrågas just enbart är elevens egen åsikt. Allt som oftast står det genealogiska perspektivet därmed ensamt. Den samtida betraktaren tillåts kolonialisera dåtida människors erfarenheter, men behöver själv bara deklarera sin egen individuella åsikt. Istället för att på ett personligt plan försöka förstå de villkor och omständigheter som präglade tidigare generationers historiska livsvärldar, så uppmanas eleven att göra sig hemmastadd på en plats som inte är dess egen.

\title{
Historia som påbjuden kunskapsform - en avslutande diskussion
}

Även om den här artikeln bygger på frågor och uppgifter fördelade på nästan hundra år, så har det huvudsakliga intresset varit riktat mot de decennier under efterkrigstiden som i tidigare forskning beskrivits som en period präglad av starka kunskapsideologiska spänningar. Måhända kan de sammantagna resultaten också förstås mot bakgrund av just denna ämnesideologiska förhandlingsprocess som tidigare accentueras i såväl Englunds, som Åström Elmersjös forskning. ${ }^{104}$ Det faktum att artikeln bygger på ett både begränsat och över tid mycket skiftande material, innebär visserligen att generaliserbarheten är mycket begränsad. Klart är dock att de 72 undersökta läromedlen, under inga förhållanden, låter sig inordnas i termer av entydiga och klart definierade perioder eller faser. Flera kunskapsideal tycks tvärtom existera samtidigt och under lång tid. ${ }^{105} \mathrm{På} \mathrm{en} \mathrm{övergripande} \mathrm{nivå} \mathrm{ger} \mathrm{artikelns}$ resultat därmed också stöd åt den tidigare forskning som pekat på hur läromedlen i påfallande liten grad tycks ha påverkats av styrdokument och läroplansreformer. Med några få undantag, förekommer liknande typer av frågor under hela efterkrigsperioden. ${ }^{106}$

På motsvarande sätt som i sentida internationella studier, dominerar den typ av slutna frågor som riktar eleverna mot ett redan på förhand fastställt svar. Den stora merparten av uppgifterna påbjuder därmed, oavsett de enskilda styrdokumentens

100 I något enstaka fall har dessa elevcentrerade frågor därtill en närmast existentiell underton. Exempelvis ombeds skolungdomarna att fundera över "varför" människor "blir landsförrädare?". Thorén, Thorén och Åberg (1991), 52.

101 Thorén, Thorén och Åberg (1991), 139. Jfr liknande iakttagelse i Persson (2018), 197-198.

102 Åsgård och Hildingsson (1999), 17.

103 Karin Sjöbeck och Birgitta Melén, Liv i förändring, 6-9, (Malmö: Interskol, 2002), 41.

104 Jfr t.ex. Englund (1986b), 478-91, 511-74; Åström Elmersjö (2017), 140-41, 258-59, 272-77.

105 Se åter tabell 2-4. Ett exempel på undantag är genomslaget för en av behaviorism och utvecklingsteknologi inspirerad uppgiftsform, som tidigare bl.a. diskuterats i: Englund (1986b), 430-33, 492-510.

106 Tabell 2-4. Jfr åter Selander (1998), 97; Persson (2019), 260; Ammert (2005), 34. 
utformning, och oavsett om frågorna rör Arabriket, Gustav II Adolf eller amerikaemigrationen, en form av kunskap som handlar om att reproducera ett givet innehåll. ${ }^{107}$ På motsvarande sätts märks genomgående jämförelsevis få frågor som lämnar utrymme för eleven att själv använda sina referenskunskaper till att resonera runt mer öppet formulerade problemställningar. ${ }^{108}$ På det hela taget framstår det därmed, på basis av denna undersökning, som svårt att hävda att skolämnet historia skulle ha blivit mer metodiskt vetenskapligt inriktat under 1900-talets sista kvartssekel. Isolerade i sig själva, ger den stora merparten av frågorna, då som tidigare, tvärtom intryck av att kunskaper i historia är något som redan finns i sig själva. Det genetiska perspektivet på historien kombineras sällan med det genealogiska. Frågorna är ställda till det förflutna, men historien tycks mer sällan öppna för att ställa frågor till eleven. Betraktade som en ämnesideologisk auktoritet skickar de tvärtom allt som oftast starka signaler om att historia bör betraktas som något helt igenom avskilt från vår egen tillvaro. Med Disch terminologi påbjuder merparten av de dryga niohundra frågor som undersökts således att eleven närmast anlägger turistens distanserade utifrånperspektiv på den historiska berättelsen. ${ }^{109}$

Även om frågornas tematik breddas något över tid är det också få frågor som öppet relaterar berättelsen om vad som varit till elevens samtid. De relativt fåtaliga försöken att angelägliggöra historien för eleven tycks på det hela taget snarare baseras på arbetsformer, än på val av innehåll. Vid sidan om att rita och skulptera i lera, sand och is, så märks därtill alltsedan 1960-talet en upprepad anmodan om att spela teater. Från 1960-talet och framåt framträder däruti också ett dryga trettiotal uppgifter som riktas mot vad bland annat Van Boxtel talat om i termer av föreställande (imagine) respektive ponerande (supposal) inlevelseuppgifter. ${ }^{110} \mathrm{I}$ det undersökta materialet förekommer dessa affektivt orienterade frågetyper, långt före den i Lpo94 uttalade ambitionen att öva elevens förmåga att leva sig in i historien. ${ }^{111}$ Dessa uppmaningar om att via den egna fantasin ställa sig i någon annans skor, innehåller emellertid påtagligt sällan explicita anmaningar om att relatera svaret till specifika historiska omständigheter. Istället för att på ett personligt plan försöka förstå innebörden av de villkor och omständigheter som präglade tidigare generationers historiska livsvärldar, så ombeds eleven, med Disch och Arendts terminologi, därmed närmast att göra sig hemmastadd på en plats som inte är den egna. ${ }^{112}$

Under 1900-talets sista kvartsekel förstärks detta elevfokus i och med inträdet av en helt ny typ av uppgift. Då framträder en form av individcentrerade åsiktsdeklarerande frågor som enbart påbjuder eleven att tycka, låtsas och tro. Detta manifesteras särskilt tydligt i det sena 1900-talets formuleringar "vad tycker du" och "vad tror du?". Med Disch terminologi skulle dessa uppmaningar närmast kunna liknas vid kolonisatörens perspektiv på den andre. Likt den som naivt hävdar att den själv kan

107 Jfr tabell 2. Jfr t.ex. Rawadieh (1998), 77; LaVere (2008) 5-6; Boone (2010), 56, 67; Mackenzie (2015), 74; Mackenzie och Steinberg (2015); Tarman och Kuran (2015), 135-36, 219; Philgence (2017), 122, 129.

108 Jfr tabell 3.

109 Disch (1994), 157, 161-62, 168; Disch, (1997), 136.

110 de Leur, Van Boxtel och Wilschut (2015), 69-84.

111 Jfr tab 4.

112 Jfr Arendt (1982), 42-44; Disch (1994), 154, 160-63. 
se något med andras ögon, signalerar dessa frågor att eleven, utan att ta hänsyn till det historiska och kulturella sammanhanget, äger rätten att assimilera andras erfarenheter; tillsynes enbart på basis av vad den själv redan tycker sig veta. ${ }^{113}$

Det ligger inte inom ramen för denna artikel att undersöka hur de olika uppgifterna mottogs eller användes. Klart är emellertid att frågorna i sig, ytterst sällan påbjuder en användning av de historiska berättelserna som ett tillfälle att, i en arendtsk mening, gå på besök hos den andre. Hanna Arendt har återkommande resonerat om hur vi, i en existentiell mening, blir till i det att vi träder fram inför andra. För att vidga möjligheterna för vad detta tillblivande kan komma att innebära, krävs dock mångfald och pluralitet. Vi behöver utmanas i våra uppfattningar om det vi redan tror oss veta. ${ }^{114}$ Rimligen skulle också läromedel i historia kunna bidra till att utvidga föreställningarna om vad som skulle kunna vara. ${ }^{115}$

Merparten av de undersökta uppgifterna tycks dock snarare handla om bekräfta något som redan är. Ofta är det den sedvanliga traditionella historisk berättelsen som skall reproduceras och konfirmeras; senare riktas emellertid bekräftelsen också mot de egna jagets invanda åsikter och redan givna föreställningsvärldar. Istället för att låta eleverna - i egentlig och verkligt öppen mening - begrunda innebörden av andra människor levnadsvillkor och umbäranden, så tycks de därmed berövas möjligheten att låta frågorna kasta ljus över, störa och utmana, den redan välbekanta egna samtida befintligheten. Den i år hundra år gamla undervisningsplanen u19 har i efterhand förknippats med en ambition att skapa stabilitet och ordning. ${ }^{116}$ De frågor som undersökts i den här artikeln, antyder att en sådan konserverande underton tycks ha karakteriserat delar av skolämnet historia långt längre fram i tiden än så.

113 Jfr Disch (1994), 157, 161-162, 168; Disch, (1997), 136.

114 Arendt (1998), 51, 202-06, 239, 271-81. Anders Persson, Lärartillvaro och historieundervisning: Innebörder av ett nytt uppdrag i de mätbara resultatens tid, (Umeå: Umeå universitet, 2017), 195-96.

115 Anders Persson, "Mormor, oönskade tyskar och en hänsynslös dansk: Några reflektioner om identifikation och mening, efter en kritisk läsning av en nyutgiven lärobok i historia för den svenska grundskolans mellanår," i Kulturell reproduktion i skola och nation: En vänbok till Lars Petterson, red. Urban Claesson och Dick Åhman (Möklinta: Gidlunds, 2016), 251-68.

116 Ammert (2014), 58. 


\section{Referenser}

\section{Källor (kronologiskt ordnade)}

Grimberg, Carl. Sveriges historia för folkskolan. Stockholm: P.A. Norstedt \& söner, 1927.

Tham, Wilhelm, red. Historien och samhället: Del I: Läro- och läsebok $i$ allmän och svensk historia samt samhällskunskap. Stockholm: AVCarlssons Bokförlag AB, 1950.

Tham, Wilhelm, red. Historien och samhället: Del II: Läro- och läsebok $i$ allmän och svensk historia samt samhällskunskap. Stockholm: AVCarlssons Bokförlag AB, 1950.

Berg, Yngve. Vår historia: II Nya tiden. Stockholm: Almqvist \& Wiksell, 1952.

Berglind, Henrik, Birger Lindell och Sam Mohlin. Förr i världen: Skildringar ur svenska historien utgivna för ungdom. Del II den nya tiden fram till 1750. Stockholm: Bokförlaget Natur och kultur, 1953.

Berglind, Henrik, Birger Lindell och Sam Mohlin. Förr i världen: Skildringar ur svenska historien utgivna för ungdom. Del III den nya tiden efter 1750. Stockholm: Bokförlaget Natur och kultur, 1955.

Wirsén, Ragnar. Historia för folkskolan. Stockholm: Svenska bokförlaget/Nordstedts, 1955.

Johannesson, Gösta. Historiska urkunder 1. Stockholm Alb. Bonniers, 1955.

Haage, Helge och Sven Wikberg. Historia: Fjärde och femte skolåren - Del 1. Stockholm: Bokförlaget Natur och kultur, 1956.

Haage, Helge och Sven Wikberg. Historia för folkskolan: Del 2 Sjätte och sjunde (åttonde) skolåren. Stockholm: Natur och kultur, 1956.

Haage, Helge och Sven Wikberg. Historia 2. Stockholm: Bokförlaget Natur och kultur, 1957.

Assar Jansson, Erik Lönnroth och Fritz Stålberg. Historia för enhetsskolans mellanstadium. Stockholm: Svenska bokförlaget Bonniers, 1958.

Wirsén, Ragnar. Historia för enhetsskolan: Del 1. Mellanstadiets kurs. Stockholm: Svenska bokförlaget Norstedts, 1959.

Hagnell, Axel och Gunnar Olander. Svensk och allmän historia för enhetsskolans mellanstadium. Gävle: Skolförlaget Gävle AB, 1960.

Tham Wilhelm, Gunnar Andner, Erik Holmberg och Yngve Berg (red). Historien och samhället. Stockholm: AVCarlssons Bokförlag AB, 1961.

Kahnberg Alf och Gösta Lindeberg. Genom tiderna: Lärobok $i$ historia för enhetsskolan, Del II årskurserna 7-8. Lund: CWK Gleerups förlag, 1961.

Dannert Leif och Waldemar Lendin. Historia för enhetsskolans högstadium 2: Årskurs 9. Stockholm: Almqvist \& Wiksell/Gebers förlag, 1961.

Wirsén, Ragnar och Karl Meurling. Historia för grundskolan årskurs 4-6. Stockholm: Svenska bokförlaget Norstedts, 1963.

Björkblom, Sixten, Lennart Dusing och Paridon von Horn. Historia för grundskolan årskurs 4-6. Stockholm: Bergvalls förlag, 1963.

Tham, Wilhelm red. Historien och samhället: Grundskolan årskurs 4-6. Stockholm: AVCarlssons Bokförlag AB, 1963.

Casserberg, Ture och Göte Rudvall red. Ur svenska historien 3: Grundskolans läsebok. Stockholm: Svenska bokförlaget Nordstedts, 1965.

Tham, Wilhelm och Bengt Åke Häger. Historia - Grundskolan Årskurs 9. Stockholm: AVCarlssons bokförlag AB, 1965. 
Graninger, Göran och Sven Tägil. Källor till historien 1. Stockholm: Uniskol, 1966. Kahnberg, Alf, Gösta Lindeberg och Lennart Sjöstedt. Genom tiderna: Lärobok i historia för grundskolan del IIIG årskurs 9. Lund: CWK Gleerups förlag, 1966.

Pehrson, Gerda. Orientering: Nya Sverige. Örebro: Bokförlaget Liber AB, 1966.

Hildingsson, Lars och Lennart Husén. Historia i grundskolan åk 8. Stockholm: Bokförlaget Natur och kultur, 1966.

Hildingsson, Lars och Lennart Husén. Historia i grundskolan. Stockholm: Bokförlaget Natur och kultur, 1967.

Sjöberg, Sven. Utvandringen till Amerika: Arbetsområden: Sverige för hundra år sedan åk 6 - Det moderna Norden växer fram åk 8. Örebro: Bokförlaget Liber AB, 1968.

Husén, Lennart och Göran Wadner. Ur folkens liv åk 9: Läsebok i historia. Stockholm: Bokförlaget Natur och Kultur, 1969.

Rystad, Göran, Birger Sallnäs och Alf Kahnberg. Ögonvittnen berättar: Historisk läsebok nya tiden. Lund: CWK Gleerups, 1970.

Jonasson, Rune K. G., Jan Gustafson och Sven Åke Johansson. Barn i alla tider - förr $i$ världen: Åk 3 och mellanstadiet. Stockholm: LT, 1971.

Hildingsson, Lars och Lennart Husén. Historia i grundskolan. Stockholm: Bokförlaget Natur och Kultur, 1971.

Kahnberg, Alf, Gösta Lindeberg och Sven Ottosson. Genom tiderna: Högstadiet. Lund: Gleerups, 1971.

Eklund, Torsten, Lars Hildingsson, Lennart Husén, Karl-Gustav Thorén och Alf Åberg. Ur folkens liv: Lärobok i historia åk 5. Stockholm: Natur och Kultur, 1971.

Eklund, Torsten, Lars Hildingsson, Lennart Husén, Karl-Gustav Thorén och Alf Åberg. Ur folkens liv: Lärobok i historia åk 6. Stockholm: Natur och Kultur, 1971.

Hildingsson, Lars och Lennart Husén. Historia 1: Grundbok, sex arbetsområden för högstadiet. Stockholm: Natur och Kultur, 1971.

Eklund, Torsten och Karl-Gustav Thorén. Nya Ur folkens liv: Historia för mellanstadiet Pilot Ö̈. Stockholm: Natur och Kultur, 1971.

Thorén Karl-Gustav och Torsten Eklund. Studiehäfte: Ur folkens liv åk 5. Stockholm: Bokförlaget Natur och Kultur, 1972.

Hildingsson, Lars, Lennart Husén och Karl Reinhold Heallqvist. Historia 3: Grundbok, åtta arbetsområden för högstadiet. Stockholm: Natur och Kultur, 1972.

Rystad, Göran och Birger Sallnäs. Ögonvittnen berättar del 2. Lund: CWK Gleerup bokförlag, 1972.

Rystad, Göran och Birger Sallnäs. Ögonvittnen berättar del 4. Lund: CWK Gleerup bokförlag, 1973.

Rystad, Göran och Birger Sallnäs. Ögonvittnen berättar del 5G. Lund: CWK Gleerup bokförlag, 1973.

Dahlgren, Bertil, Göran Ejeman, Ragnar Henriksson och Lennart Skaaret.Historia 3M, Grundbok Häfte B, Mellanstadiet. Stockholm: Almqvist och Wiksell 1973

Hildingsson, Lars och Lennart Husén. Historia 1: Grundbok, fem arbetsområden för högstadiet. Stockholm: Natur och kultur, 1974.

Eklund, Torsten, Lars Hildingsson, Lennart Husén, Karl-Gustav Thorén och Alf Åberg. Ur folkens liv: Lärobok i historia åk 6. Stockholm: Natur och Kultur, 1975.

Åberg, Alf, Lennart Husén, Hugo Serdén och Karl Gustav Thorén. Ur folkens liv: Läsebok i historia för femte årskursen. Stockholm: Natur och Kultur, 1976. 
Eklund, Torsten, Lars Hildingsson, Lennart Husén, Karl-Gustav Thorén och Alf Åberg. Ur folkens liv 3: Historia för mellanstadiet, grundbok. Stockholm: Bokförlaget Natur och kultur AB, 1977.

Eklund, Torsten, Lars Hildingsson, Lennart Husén, Karl-Gustav Thorén och Alf Åberg, Ur folkens liv 2: Historia för mellanstadiet, grundbok. Stockholm: Bokförlaget Natur och kultur AB, 1978.

Thorén, Karl-Gustav och Alf Åberg, Historia 3: Natur och kulturs läseböcker för mellanstadiet. Stockholm: Natur och Kultur, 1978.

Andersson, Lars, Börje Bergström, Nicke Hedin och Bengt Mohall. Historia 2 Parasoll. Stockholm: Liber läromedel, 1979.

Andersson, Lars, Börje Bergström, Bengt Brodow, Nicke Hedin och Bengt Mohall. Historia 3 Parasoll. Stockholm: Liber läromedel, 1980.

Silvén-Garnert, Eva och Svedelid Olov. Vida världen: Historia 2. Grundboken. Stockholm: Almqvist \& Wiksell, 1982.

Warne, Kjell och Lars Hildingsson. Studiebok, historia version II. Stockholm: Bokförlaget Natur och kultur, 1987.

Häger, Bengt Åke. Följ med genom tiderna: SO Historia Högstadieboken. Lund: Dialogos, 1989.

Öhman, Christer. Historia för högstadiet. Uppsala: Esselte studium, 1989.

Fallström, Jan-Olof, Lars Hildingsson och Göran Wadner. Levande historia: Läsebok 2. Stockholm: Natur och kultur, 1990.

Thorén, Berit, Karl-Gustav Thorén och Alf Åberg. Läsebok i historia 4 - Stormaktstiden. Stockholm: Natur och kultur, 1991.

Almgren, Bengt, Hans Thorbjörnsson och Hans Tillman. Historia 1: En lärobok för grundskolans senare del, SO Direkt. Stockholm: Bonniers utbildning, 1996.

Körner, Göran och Lars Lagheim. Historia: Den nya tiden - Franska revolutionen och 1800-talet, Puls 7. Stockholm: Natur och kultur, 1996.

Öhman, Christer. Historia 3: Rondo. Stockholm: Almqvist \& Wiksell, 1996.

Almgren, Bengt, Berndt Tallerud, Hans Thorbjörnsson och Hans Tillman. Historia 1: En lärobok för grundskolans senare del, SO Direkt. Stockholm: Bonniers utbildning, 1998.

Åsgård, Ingrid och Lars Hildingsson. Levande historia: Studiebok årskurs 6. Stockholm: Natur och kultur, 1999.

Öhman, Christer. Historia 1: Rondo. Stockholm: Almqvist \& Wiksell, 2001.

Sjöbeck, Karin och Birgitta Melén. Liv i förändring, 6-9. Malmö: Interskol, 2002.

Hedin Marika, Robert Sandberg. Historien pågår: Historia för grundskolans senare år. Stockholm: Almqvist \& Wiksell, 2002.

Ivansson, Elisabeth och Mattias Tordai. Historia - SO.S, del 1 av fyra. Stockholm: Almqvist \& Wiksell, 2003a.

Ivansson, Elisabeth och Mattias Tordai. Historia - SO.S, del 2 av fyra. Stockholm: Almqvist \& Wiksell, 2003b.

Ivansson, Elisabeth och Mattias Tordai. Historia - SO.S, del 3 av fyra. Stockholm: Almqvist \& Wiksell, 2003b.

Almgren Hans, Stefan Wikén och Birgitta Almgren. Historia kompakt. Malmö: Gleerups, 2008.

Körner, Göran och Lars Lagheim. Impuls: Stadiebok Historia 1-3 för grundskolans senare del. Stockholm: Natur \& kultur, 2009. 
Nilsson, Erik och Hans Olofsson och Rolf Uppström. Hi: Historia 7-9, Utkik. Malmö: Gleerups, 2013.

Ivansson, Elisabeth och Mattias Tordai. Historia - Ämnesboken. Stockholm: Liber, 2015.

\section{Litteratur}

Ammert, Niklas. "Folkvilja, etikett eller jordbruksteknik?: En historiedidaktisk analys av synen på demokrati i historieläroböcker 1960-2003." Utbildning och demokrati, 14, no. 3 (2005), 31-50.

Ammert, Niklas. Det osamtidigas samtidighet: Historiemedvetande i svenska historieläroböcker under hundra år. Lund: Lunds universitet, 2008.

Ammert, Niklas. "Contact and contrast: The subject of history and its relation to students 1905-2005." International Journal of Historical Learning, Teaching and Research 12, no. 2 (2014), 46-63.

Ammert, Niklas. "Historieläromedel: En forskningsöversikt." Humanetten 37 (2016), 140-53.

Ammert, Niklas och Heather Sharp. "Working with the Cold War: Types of Knowledge in Swedish and Australian History Textbook Activities." Journal of Educational Media, Memory, and Society 8, no. 2 (2016), 58-82.

Andolf, Göran. Historien på gymnasiet: Undervisning och läroböcker 1820-1965. Uppsala: Uppsala universitet och Skandinavien university books Esselte studium, 1972.

Arendt, Hannah. Lectures on Kant's Political Philosophy. Chicago: The University of Chicago Press, 1982.

Arendt, Hannah. Människans villkor: Vita activa. Göteborg: Daidalos, 1998.

Armbruster, Bonnie B. och Thomas H. Anderson. "What Did You Mean by That

Question?: A Taxonomy of American History Questions." Report No308, University of Illinois at Urbana-Champaign, 1984.

Bergum Johanson, Lisbeth. "The Norwegian Curriculum in History and Historical Thinking: A Case Study of Three Lower Secondary Schools." Acta Didactica Norge 9, no.1 (2015), 1-24.

Berkeley, Sheri, Margaret E. King-Sears, Brittany L. Hott och Katherine Bradley-Black. "Are History Textbooks More, "Considerate" After 20 Years?" The Journal of Special Education 47, no. 4 (2014), 217-30.

Bharath, Pranitha. "Analysing Historical Enquiry in School History Textbooks." Diss., University of KwaZulu-Natal, 2018.

Boone, Paul T. "Explicit Instruction in United States History Textbooks Exercises: The Role of Exercises in Navigating and Critically Evaluating Textbooks." Diss., University of Nevada, 2010.

Christophe, Barbara, Annekatrin Bock, Eckhardt Fuchs, Felicitas Macgilchrist, Marcus Otto, och Steffen Sammler. "New Directions." I The Palgrave Handbook of Textbook Studies, red. Eckhardt Fuchs och Annekatrin Bock, 413-22. New York: Palgrave Macmillan, 2018.

Danielsson Malmros, Ingmarie. Det var en gång ett land: Berättelser om svenskhet $i$ historieläroböcker och elevers föreställningsvärldar. Lund: Lunds universitet, 2012.

de Leur, Tessa, Carla Van Boxtel och Arie Wilschut. "'Just Imagine ...: Students' Perspectives on Empathy Tasks in Secondary History Education." International Journal of Historical Learning, Teaching and Research 13, no. 1 (2015), 69-84. 
Disch, Lisa J. Hanna Arendt and the Limits of Philosophy. New York: Cornell University Press, 1994.

Disch, Lisa. "'Please Sit Down, but Don't Make Yourself at Home': Arendtian 'Visiting' and the Prefigurative Politics." I Hanna Arendt \& the meaning of politics, red. Craig Calhoun och John McGowan, 132-65. Minneapolis: Minnesota Press, 1997.

Englund, Boel. "Lärobokskunskap, styrning och elevinflytande." Pedagogisk forskning i Sverige 4, no. 4 (1999), 327-48.

Englund, Tomas. Samhällsorientering och medborgarfostran i svensk skola under 1900-talet: Kap 1-4. Uppsala: Uppsala universitet, 1986a.

Englund, Tomas. Samhällsorientering och medborgarfostran i svensk skola under 1900-talet: Kap 5-8. Uppsala: Uppsala universitet, 1986b.

Englund, Tomas. Läroplanens och skolkunskapens politiska dimension. Göteborg: Daidalos, 2005.

Fey, Carl-Christian och Eva Matthes. "Textbook Quality Criteria and Evaluation." I The Palgrave Handbook of Textbook Studies, red. Eckhardt Fuchs och Annekatrin Bock, 157-68. New York: Palgrave Macmillan, 2018.

Fuchs, Eckhardt och Annekatrin Bock, red. The Palgrave Handbook of Textbook Studies. New York: Palgrave Macmillan, 2018.

Fuchs Eckhardt och Kathrin Henne. "History of Textbook Research." I The Palgrave Handbook of Textbook Studies, red. Eckhardt Fuchs och Annekatrin Bock, 25-56. New York: Palgrave Macmillan, 2018.

Grever, Maria och Tina Vlies. "Why National Narratives Are Perpetuated: A Literature Review on New Insights from History Textbook Research." London Review of Education (2018), 286-301.

Gustafsson, Jörgen. Historielärobokens föreställningar: Påbjuden identifikation och genreförändring $i$ den obligatoriska skolan 1870-2000. Uppsala: Uppsala universitet, 2017.

Halldén, Ola. Elevernas tolkning av skoluppgiften: En beskrivning av elevers förhållningssätt till lärares frågor. Stockholm: Stockholms universitet, 1982.

Harmon, Janis M., Wanda B. Hedrick och Elizabeth A. Fox. "A Content Analysis of Vocabulary Instruction in Social Studies Textbooks for Grades 4-8." The Elementary School Journal 100, no. 3 (2000), 253-71.

Haue, Harry. "Transformation of History Textbooks from National Monument to Global Agent." Nordidactica 1, (2013), 80-89.

Holmén, Janne. Den politiska läroboken: Bilden av USA och Sovjetunionen i norska, svenska och finländska läroböcker under kalla kriget. Uppsala: Uppsala universitet, 2006.

Hovland, Brit Marie. Historie som skolefag og dannelsesprosjekt 1889-1940: En historiografi ut fra folkeskolens historieloerebøker. Oslo: Universitetet i Oslo, 2016.

Johnsson Harrie, Anna. Staten och läromedlen: En studie av den svenska statliga förhandsgranskningen av läromedel 1938-1991. Linköping: Linköpings universitet, 2009.

Juuhl, Gudrun Kløve, Magnus Hontvedt och Dagrun Skjelbred. ”Læremiddelforsking etter LK06 - Eit kunnskapsoversyn." Oslo: Uddanningsdirektoratet, 2010.

Karlsson, Klas-Göran. "Läroboken och makten: Ett nära förhållande." I Läromedelsstudier i teori och praktik, red. Niklas Ammert, 43-62. Lund: Studentlitteratur, 2011. 
Kjeldstadli, Knut. Det förflutna är inte vad det en gång var. Lund: Studentlitteratur, 1998.

Lavere, David B. "The Quality of Pedagogical Exercises in U.S. History Textbooks." The Social Studies 99, no. 1 (2008), 3-8.

Lévesque, Stephane. Thinking historically: Educating students for the twenty-first century. Toronto: Buffalo, 2008.

Lorentzen, Svein. Ja, vi elsker... Skolebøkene som nasjonsbyggere 1814-2000. Oslo: Abstrakt forlag, 2005.

Mackenzie, Basil. "Doing School History as Portrayed in Assessment Tasks Found in the European Expansion and Conquest in the 15th to 18th Centuries Units Contained in a Sample of Grade 10 South African CAPS-Compliant History Textbooks." Diss., University of the Witwatersrand, 2015.

Mackenzie, Basil och Carola Steinberg. "Recognising the Academic and Political Purposes Embedded in History Textbook Assessment Tasks." Yesterday and Today 14 (2015), 125-50.

Nery-Cura, Ma. Lourdes S. och Allan B. de Guzman. "A Rhizotextual Analysis of Philippine Secondary Textbooks in History." Education Research Policy Practise, 17 (2018), 173-75.

Persson, Anders. "Mormor, oönskade tyskar och en hänsynslös dansk: Några reflektioner om identifikation och mening, efter en kritisk läsning av en nyutgiven lärobok i historia för den svenska grundskolans mellanår". I Kulturell reproduktion i skola och nation, red. Urban Claesson och Dick Åhman, 251-68. Möklinta: Gidlunds, 2016.

Persson, Anders. Lärartillvaro och historieundervisning: Innebörder av ett nytt uppdrag i de mätbara resultatens tid. Umeå: Umeå universitet, 2017.

Persson, Anders. "Americans and Russians as Representatives of 'Us' and 'Them': Contemporary Swedish School History Textbooks and their Portrayals of the Central Characters of the Cold War." I Teaching the Cold War: International Perspectives on Memory Practices in Educational Media and in the Classroom. red. Barbera Christophe et.al., 107-35. New York: Palgreaves, 2019.

Persson, Helén. Historia i futurum: Progression $i$ historia $i$ styrdokument och läroböcker 1919-2018. Lund: Lunds universitet, 2018.

Philgence, Kern E. "A comperative schema Theory-based Analysis of World History Print Textbooks and E-textbooks." Diss., Nortcentral University, 2017.

Rawadieh, Saleh Moh'd. "An Analysis of the Cognitive Levels of Questions in a Jordaniean Secondary Social Studies Textbook According to Bloom's Taxonomy." Diss., Ohio University, 1998.

Repoussi, Maria och Nicole Tutiaux-Guillon. "New Trends in History Textbook Research: Issues and Methodologies Towards a School Historiography." Journal of Educational Media, Memory and Society 2, no. 1 (2010), 154-70.

Retz, Tyson. "A Moderate Hermeneutical Approach to Empathy in History Education." Educational Philosophy and Theory 47, no. 3 (2015), 214-26.

Selander, Staffan. Lärobokskunskap: Pedagogisk textanalys med exempel från läroböcker i historia 1841-1985. Lund: Studentlitteratur, 1988.

Sharp, Heather och Niklas Ammert. "Primary Sources in Swedish and Australian History Textbooks: A Comparative Analysis of Representations of Vietnam's Kim Phuc." International Journal of Historical Learning, Teaching and Research 14, no. 2 (2017). 
Spjut, Lina. Att (ut)bilda ett folk: Nationell och etnisk gemenskap i Sveriges och Finlands svenskspråkiga läroböcker för folk- och grundskolan åren 1866-2016. Örebro; Örebro universitet, 2018.

Tarman, Bulent och Burcin Kuran. "Examination of the Cognitive Level of Questions in Social Studies Textbooks and the Views of Teachers Based on Bloom Taxonomy." Educational Sciences: Theory \& Practice 15, no. 1 (2015).

Tingsten, Herbert. Gud och fosterlandet: Studier i hundra års skolpropaganda. Stockholm: P.A. Norstedts \& Söners förlag, 1969.

Thorp, Robert. "Representation and Interpretation: Textbooks, Teachers, and Historical Culture." IARTEM e-Journal 7, no. 2 (2015).

Yeager, Elizabeth A., Stuart J. Foster, Sean D. Maley, Thom Anderson och James W. III Morris. "Why People in the Past Acted as They Did: An Exploratory Study in Historical empathy." The International Journal of Social Education 13, no. 1 (1998), 8-24.

Zander, Ulf. "Att legitimera och bli legitimerat: Historieämnet förr och nu i Sverige och annorstädes." I Historiedidaktiska utmaningar, red. Hans Albin Larsson, 32-68. Jönköping: Jönköping University Press, 1998.

Åström Elmersjö, Henrik. "Historia och konflikter: Historiekultur och historieundervisning inom, över och bortom gränser." Historisk tidskrift 134, no. 2 (2014), 267-277.

Åström Elmersjö, Henrik. Norden, nationen och historien: Perspektiv på föreningarna Nordens historieläroboksrevison 1919-1972. Lund: Nordic Academic Press, 2013.

Åström Elmersjö, Henrik. En av staten godkänd historia: Förhandsgranskning av svenska läromedel och omförhandlingen av historieämnet 1938-1991. Lund: Nordic Academic Press, 2017. 